FTAMP 03.29.00

\title{
Сайлан Б.С.
}

тарих ғылымдарының докторы, профессор, әл-Фараби атындағы Қазақ ұлттық университеті, Қазақстан, Алматы қ., e-mail: b_sailan1967@mail.ru

\section{АУҒАН СОҒЫСЫ ҚАААЙ АЯҚТАААЫ?}

1979-1989 жылдары болған Ауған соғысына деген көзқарас пен оған берілген баға әлі ұзақ жылдар бойы талқыналары анық. Өйткені бұл соғыс түйіні - көптеген халықаралық, саяси, идеологиялық, әлеуметтік-экономикалық, және әскери аспектілерді қамтыды. Соның ішінде он жыл бойы Ауған жерінде айқасқан 40-армияның Ауғанстанды тастап шығуы мақаланың негізгі арқауы болып саналады. КСРО үшін көптеген қиыншылықтар әкелген бұл соғыстың қалай аяқта^ғаны еңбекте жан-жақты талданады. 1980 жылдардың басынан әскерді Ауғанстаннан әкету туралы шешімнің халықаралық деңгейде жүзеге аспағандығы, ол жөніндегі келіссөздердің нәтижесіз аяқталғаны, соғыстың жылдан-жылға созыла түсу себептері айтылады. Тек 1985 жылдан бастап Ауған соғысын аяқтау, бұл елден кеңес әскерін алып кету жұмыстарының нәтижелі табыстарға жете бастағандығы қарастырылады. Кеңес әскерін 1989 жылы Ауғанстаннан әкетуде Женева келісімінің маңызды рөл атқарғаны және осы келісімге қатысушы елдердің ұстанымдары барынша анық сипатталып, соғыстың мәресіне жету себептері толық ашылады.

Түйін сөздер: КСРО, БҰҰ, соғыс, әскер, келісім, шығын, оппозиция, қолбасшы, босқын.

Sailan B.S

Doctor of Historical science, Professor, al-Farabi Kazakh National University, Kazakhstan, Almaty, e-mail: b_sailan1967@mail.ru

\section{How did the Afghan war end?}

To this day, the Afghan war, which occurred in 1979-1889, was widely discussed by the people. It includes international, political, ideological, socio-economic, military aspects. In addition, the main theme of this article is the withdrawal of 40 armies within 10 years to the territory of Afghanistan. This document details the completion of the Afghan war, which caused many difficulties in the life of the USSR. The absence of a formal international agreement on the withdrawal of the Soviet army from Afghanistan in the 1980s led to a deterioration of the condition and pulled the warrior for several years. Only in 1985, an agreement was reached on the withdrawal of Russian military facilities from Afghanistan, as well as on the withdrawal of soldiers. This article openly emphasizes that the Geneva Agreement, signed in 1989, played an important role in the withdrawal of the Soviet army from Afghanistan.

Key words: USSR, UN, war, army, contract, damage, opposition, commanding, refugees.

Сайлан Б.С.

Аоктор исторических наук, профессор, Казахский национальный университет имени аль-Фараби,

Казахстан, г. Алматы, e-mail: b sailan1967@mail.ru

Как закончимась Афганская война?

По сей день Афганская война, прошедшая в 1979-1889 годах, широко обсуждается среди народа. Главной причиной тому является его заключение. Оно включает в себя международные, политические, илеологические, социально-экономические, а также военные аспекты. К тому же главным лейтмотивом Аанной статьи является вывод служащих в течение 10 лет на территории Афганистана 40 армий. В Аанной работе подробно описывается заключение Афганской войны, принесшей много труАностей в жизни КСРО. Отсутствие официального межАунароАного согласия 
о выведение Советской Армии из Афганистана с 1980 года стало причиной затянувшейся войны на несколько лет. Только в 1985 году было получено согласие на выведение российских войсковых объектов из Афганистана, а также окончание войны. В данной статье открыто подчеркивается, что Женевское соглашение, подписанное в 1989 году, сыграло важную роль в выводе Советской Армии из Афганистана.

Кмючевые слова: СССР, ООН, война, армия, Аоговор, ущерб, оппозиция, командующий, беженцы.

\section{Кіріспе}

1979 жылғы 25 желтоқсанда Кеңес әскерлерінің шектеулі контингенті Ауғанстан шекарасынан өтті. Сөйтіп, 1989 жылдың 15 ақпанына дейін, яғни 10 жылға жуық ол елде соғыс жүргізді. Бұл соғыс төңірегінде сөз қозғайтын болсақ, бұл соғыстың ақиқаты әлі толық айтылып біткен жоқ. Әрине, Ауғанстан соғысы төңірегінде баспасөз беттерінде жарияланып жатқан жарияланымдар мен еңбектер аз емес. Ресми органдар мен әлгіндей жарияланымдар тарапынан бұл соғыс кейінгі уақытқа дейін әділетті соғыс тұрғысында бағаланып, интернационалдық көмек беру ретінде айтылып келді. Кейінгі жылдары бұл соғыстың әділетсіз, басқыншылық және пайдасыз соғыс екеніне көзіміз жете бастады.

Сөйтіп, Ауған соғысы тарихқа енді. Соңғы жылдары осы соғысқа жан-жақты талдау жасап, ақиқатын ашып, бұрынғы Кеңес Одағының құрамындағы басқа республикалар сияқты біздің республикамызға әкелген қайғы мен қасірет, шығын мен зардап, өкініш пен орны толмас қайғының бетін ашып жазған ғылыми еңбектер жарыққа шыға бастады. Соның ішінде бұл соғыстың қалай аяқталғаны туралы тура тұжырым беретін еңбектер әлі де қажет-ақ. Өйткені тарихқа енген Ауған соғысын аяқтау мәселесі әрі ұзақ, әрі күрделі болғанын біреу білсе, біреу білмеді. Сондықтанда Ауған соғысының аяқталу тарихын анық, әрі айқындап жазу, терең тұжырымдар арқылы талдау, оны жете зерттеу мәселесі өзекті мәселе екендігі хақ.

\section{Методология}

Зерттеу жұмысының деректік базасын Қазақстандағы Ауған соғысы ардагерлерінің қоғамдық бірлестігі мен ұйымдарындағы мұрағат қорлары, 40-шы армия қолбасшылары мен бұрынғы әскери және дипломатиялық қызмет атқарған лауазым иелерінің естеліктері, сонымен қатар осы соғыс жайында жарияланған құжаттар мен материалдар, әдебиеттер мен деректер құрайды. Соғысқа қатысушылардың мәселесін тарихи құжаттар арқылы қарастыру - кеңес әскерлерінің басынан кешкен қиындықтарын, соғыстан қажыған ауған халқының қалай босқындыққа ұшырағанын түсінуге негіз болады. Зерттеліп отырған мәселені оқып білу мен тарихи шындықты анықтауда салыстырмалы және жан-жақты баға беретін концепция қарастырылды. Әлемдік тарих дамуының заманауи кезеңі адамзат баласының жинақтауымен қоғамдық дамудың түрлі жолдары мен формаларын, тарихи оқиғалардың мән-мағынасы мен бағытын, тұтастығы мен өзара тәуелділігі туралы тарихи тәжірибені толық қамтиды.

\section{Негізгі бөлім}

1980 жылдардың ортасына қарай, Ауғанстандағы соғыс КСРО үшін көптеген қиын сынамалар мен ірі саяси және экономикалық шығындар әкелгені анық біліне бастады. Халықаралық тұғырдағы жағдай одан әрмен қиындай түсті. Ауғанстанда әскерлердің ірі топтарының шоғырлануы ел экономикасына ауыртпалық түсірді. Елдің әр түпкірінде соғыста қаза болған офицерлер мен жауынгерлер жерге көміліп, қоғам ішінде кінараттайтын жағдай үдеді. Осының барлығы халық арасында наразылық тудырды. Ауғанстаннан әскерді шығару туралы және соғысты тоқтату жайлы қатаң шешімдер қажет болды.

Мұндай үрдіс 1980 жылдары басталғанымен ешқандай нәтиже бермеді. 1980 жылы 22 нурызда өткен партия съезінен кейін КСРО МҚКнің төрағасы Ю.В. Андропов төрағалық еткен Кремльде ауған проблемасы қаралған жиын өткізілді. Әскери мамандар Ауғанстаннан кеңес әскерін біртіндеп алып кетуді ұсынды. Бірақ ешқандай нәтижелі реакция болмады. Бірақ, 1981 жылы Саяси бюро Сыртқы істер министрі А.А. Громыконың Ауғанстаннан Кеңес әскерлерін шығаруды мақсат еткен дипломатиялық процесті ұйымдастыруына қолдау көрсетті. Кеңес басшылығының мұндай ұстанымын БҰҰ ұйымы байқады. 1982 жылы 
Л.И. Брежневті жерлеу рәсімі қарсаңында кеңес үкіметінің жаңа басшысы Ю.В. Андропов Пәкістан президенті Зия Уль-Хасанмен кездесті. Кездесу барысында Ауған мәселесі сөз болды. 1983 жылы 28 наурызда Ю.А. Андропов БҰҰ Бас хатшысымен кездесу барысында Ауған мәселесін бейбіт жолмен шешуге мүдделі екенін білдірді. Алайда АҚШ әкімшілігінің Ауғанстан қақтығысынан барынша пайда табуы және КӘШК соғыс қимылдарына тарту ниеті БҰҰ-ның бұл істегі қызметіне қиындық тудырды. 1984 жылы ақпанда Ю.В. Андропов қайтыс болғаннан кейін БҰҰ-ның Ауғанстандағы қақтығысты тоқтату мақсатында бағытталған шаралары бәсеңдеді. Бұған қоса АҚШ ауған оппозициясын қолдауды күшейтті (biofile.ru).

Ауғанстанға әскер енгізудің қателік болғанын, 1985 жылы билікке келген Михайл Горбачев бастаған елдің жаңа басшылығы толық түсінді. Бұл соғыстың Кеңес Одағына «мырыш табыт» пен әлемдік айыптаулардан басқа ештеңе бермейтінін Горбачев білді. 1986 жылдың қараша айында КОКП ОК Саяси бюросының отырысында М.С. Горбачев: «Қазіргі уақытқа дейін біз Ауғанстанда алты жыл бойы соғыс жүргізудеміз. Егер біз айла тәсілімізді өзгертпесек, 20 немесе 30 жыл бойы соғыса береміз. Біз қысқа мерзім ішінде мұны тоқтатуымыз керек» - деген ойын жариялады (Гареев, 1996: 84).

Осы жылдары Бабрак Кармал және басқа да ауған басшыларымен болған кездесу мен жиналыстарда Ауғанстандағы жағдайды саяси реттеудің жолдарын белсенді түрде іздеу және кеңес әскерлерін шығару туралы сұрақтар қарастырылды. Бастапқы қадам ретінде 1986 жылдың қазан айында Ауғанстаннан 6 полк: екі мотоатқыштар, бір танкішілер және үш зенитшілер 12 мың адамнан тұратын әскер шығарылды. Сонымен қатар, бір уақытта, ауған мәселесін саяси реттеу бойынша дипломатиялық қадамдар қабылданды (Васильев, 2014: 87).

АҚШ, Пәкістан, Иран және басқа да қызығушылық танытқан елдердің өкілдерімен қарқынды келіссөздержүргізілді. 1986-1987жылдары Ауғанстанда туындаған жағдай, орталық үкімет пен оппозиция күштері арасындағы орнаған тепе-теңдік ауған дағдарысын шешудің соғыссыз жолдарын іздеу қажеттілігіне итермеледі. Жаңа бағытты іске асыру үшін жаңа адамдар керек болды. 1987 жылдың 3 қаңтарында билік басына Наджибулла келгеннен кейін «Ұлттық татуласу туралы» АДР Революциялық кеңесінің Декларациясы қабылданды, онда атысты тоқтатып, ұлттық бейбітшілік орнату мақсатында, уақытша коалициялық мемлекет құру және жалпы дауыс беруді өткізу, үкіметтегі министрліктің лауазымдарының бір бөлігін оппозиция өкілдеріне ұсыну туралы нақты ұсыныстар келтірілді.

Оппозиция мұндай саясатты қабыл алмағанмен, ұлттық татуласу саясатын жариялау Ауғанстанның орталық үкіметінің беделін асырып, БҰҰ Бас хатшысының жеке өкілі Д. Кордовес арқылы 1982 жылдан бері нәтижесіз жүргізіліп жатқан, ауған-пәкістандық келіссөздердің іске асырылуына жаңа серпін берді.

1988 жылдың 7 сәуірінде Ташкентте КОКП ОК-ның Бас хатшысы М.С. Горбачев пен АДР Президенті М. Наджибулла арасында кездесу болып, қақтығысты тоқтату мен Ауғанстандағы кеңес әскерлерінің шектеулі контингентінің тұжырымы туралы жариялады. Бір аптадан кейін, 14 сәуірде, АДР-ғы жағдайды саяси реттеу туралы Женева келісіміне қол қойылды. Қол қойғандар қатарына КСРО, АҚШ, Ауғанстан мен Пәкістан кірді. Ауғанстан мен Пәкістан бірбіріне қол сұқпаушылық және басып кіруден бас тарту қағидасына қол қойса, КСРО мен АҚШ өкілдері халықаралық кепілділік жөніндегі Декларацияға қол қойды. Кеңес Одағы өз контингентін 9 айлық мерзімде алып шығуға, ал Құрама Штаттар мен Пәкістан өз тараптарынан қарулы оппозицияны қолдауды тоқтатуға міндеттелді (eurasia.expert).

1988 жылы 15 мамырда Ауғанстан аумағынан кеңес әскерлерін шығару басталды, алайда қараша айындағы моджахедтердің әрекеттерінің жандана түсуі, үдерістің жылдың аяғына дейін қалдырылуына әкелді. Жағдайдың орнығуы мен әскерилер арасындағы шығынды азайту үшін оппозицияның белсенді күштерін жоюға ракеталық әскери бөлімшелер енгізілді. Олар душмандардың шабуылын жоюға баллестикалық зымыранды 92 рет жіберді. Дегенмен, 1988 жылдың тамызына дейін КӘШК-нің жеке құрамының шамамен жартысы Ауғанстаннан шығарылды (Гареев, 1996: 84).

Егер Кеңес Одағы Женевада келісімінде өзіне алған міндеттерді біртіндеп орындаса, қалған мемлекеттер орындамады. Иран болса төрт ел қабылдаған Женева келісімін мүлде мойындамады, мүдделі бесінші мемлекет болса да қол қоюдан бас тартты. АҚШ, Пәкістан тағы да басқа елдер келісілген шарттарды өрескел бұзды.

Пәкістан территориясында Ауғанстан территориясына кіріп соғыс қимылын жүргізу мақсатында қарулы құрылымдардың базалары 
жасақталды. Женева келісімінің осындай және басқа да қағидаларының бұзылуына жол берілді. Батыстық елдер Ауғанстандағы жағдайдың реттелгенін қаламады. АҚШ президентінің ұлттық қауіпсіздік жөніндегі көмекшісі 3.Бжезинский: «Саяси реттеудің қажеті жоқ, реттеу үшін билікті басқаның қолына өткізу керек деген ойларын» - тіке мәлімдеді (Ляховский, 1991: 77).

Ауғанстан Сыртқы істер министрлігінде 1988 жылы жарық көрген «Ақ кітапта» (Белая книга) «Бүкіл адамзат қамы үшін Женева келісімдерін орындау» тақырыбында АҚШ пен Пәкістан тарапынан келісімдердің сан рет бұзылғандығы баяндалады.

Пәкістан территориясында бұрынғыдай қарулы ауған оппозициясын үйретуге арналған жаттықтыру орталықтары болды. Андарек лагерінде, Пешавардан сәл әріректе, Пәкістан әскери нұсқаушылары ауыр қарумен ату және мина қою бойынша 800-ден астам экстремистерді үйреткен. Пәкістан провинциясы Белдужистанда орналасқан Яро лагерінде экстремистерді Кабул, Кандагар, Желалабад қалаларында жарылыс операцияларын өткізуге дайындады. Жалпы Пәкістан территориясында 200 жаттықтыру орталықтары болды.

Кейбір мәліметтер бойынша кеңес әскерлерінің ауған жерінен шығарылуы басталған екі ай ішінде қарулы оппозиция 2914 әскери акция, 96 іріткі салу мен террорлық актілерін жасады, нәтижесінде 448 адам қайтыс болып, 500 адам жараланды. Тек мамыр мен тамыз айлары аралығында Кабулда 200 ракета мен 30 артиллериялық снаряд атқыланды. 63 жарылыстың алды алынды. 154 адам қайтыс болды, 206 адам жараланды. Олардың арасында қарттар, әйелдер мен балалар бар еді. Пәкістан өкіметі БҰҰ бақылаушылары жұмыстарына кедергі келтірумен болды, олармен ынтымақта жұмыс істеуден бас тартты. 1988 жылы 4-6 маусымда БҰҰ бақылаушылары Ауғанстан шағымына байланысты Пешавар және Парачинар қалаларында болды. Алайда оларға қарулы үкіметке қарсы топтарға қару жеткізіп беретін керуен дайындалатын мекендерге баруға тыйым салынды (Сайлан, 2001: 175).

Келісімді бұзудың тағы бір үлгісі Пәкістанның ауған босқындарын қайтаруын бөгеу еді. Босқындарды қабылдау үшін ауған басшылығы шекаралас аудандарда 23 қонақ үй, 10 лагерь мен отанына оралушыларға арналған 27 орталық құрды. Бұның бәрі 10 мың бос- қынға мөлшерленді. 1988 жылдың тамызына таяу уақытта 150 мыңнан астам босқын Отанына оралды. Алайда олардың көпшілігі мұндай мүмкіншілікке ие бола алмады. Ауған оппозициясының талабы бойынша Пешевардағы босқындар лагері Пәкістан әскерімен қоршалды, олар ауған оппозициясымен бірге күзет қызметін атқарды. Одан басқа Пәкістан өкіметі шекаралас аудандарға күзет орнатып, өту жолдарын миналады. 1988 жылдың 1 шілдесінде 65 босқын Ауғанстанға Матасангар өту жолымен оралғысы келді. Қарулы экстремистер Пәкістан өкіметінің хабар беруі арқылы оларға оқ жаудырды. 26 адам өлтіріліп, қалғандары кері қайтарылды (Сайлан, 2001: 175).

Халықаралық ұйымдардан келіп түскен гуманитарлық жәрдемдердің көп бөлігі «жетілік альянсы» мен Пәкістан шенеуніктері арқылы тоналды. Нәтижесінде көптеген босқындар аштықтан қиналып, жұқпалы аурулардан қайтыс болып жатты. Алипур лагерінде бір ай ішінде 18 адам қайтыс болды.

Женева келісіміне қол қойылғаннан кейін кеңестік әскери бөлімшелерге 555 рет оқ жаудырылды, 26 рет әуежайлар оқ астында қалды. 400 рет сақшы тұрағына шабуыл жасалды. Шабуыл тіпті үкіметтік ауған әскерлеріне де жасалынды. 1989 жылдың 15 ақпанына дейін қаруланған оппозиция қолынан 6954 адам қаза тапты, 12220 адам жарақат алды. Олардың көпшілігі бейбіт тұрғындар еді. Соңғы бір жарым ай ішінде 1989 жылдың 15 ақпанына дейін 39 кеңестік әскери қызметкер қаза тапты (Гареев, 2002: 88).

Пәкістандық билік өкілдері БҰҰ бақылаушыларының жұмысына кедергі жасауға тырысып бақты. Женева келісімінің шартына қарамастан олар ауғандық босқындардың қайтып келуіне кедергі жасады. Босқындарды қабылдау үшін Ауған үкіметі 23 қонақ үй, 10 қабылдау лагерін және 10 мың адамдық отанына оралушыларға арналған 27 орталық құрды. Осы мақсат үшін кеңес әскері тастап кеткен әскери қалашықтарды да берді. Тамыздың басында Ауғанстанға 150 мың босқын оралды. Бірақ ауған оппозициясының сұрауымен пәкістандық полицейлер және әскерилер босқындар лагерін қоршап, олардың отанына оралуына барынша кедергі келтірді (Гареев, 2002: 88).

Женева келісімінде белгіленгендей Ауғанстаннан 1989 жылы 15 ақпанда соңғы кеңес әскерлерінің әкетілуі аяқталды. Кеңес Одағы Женева келісімін мүлтіксіз белгіленген мерзімде орындады (Правда, 1989). 


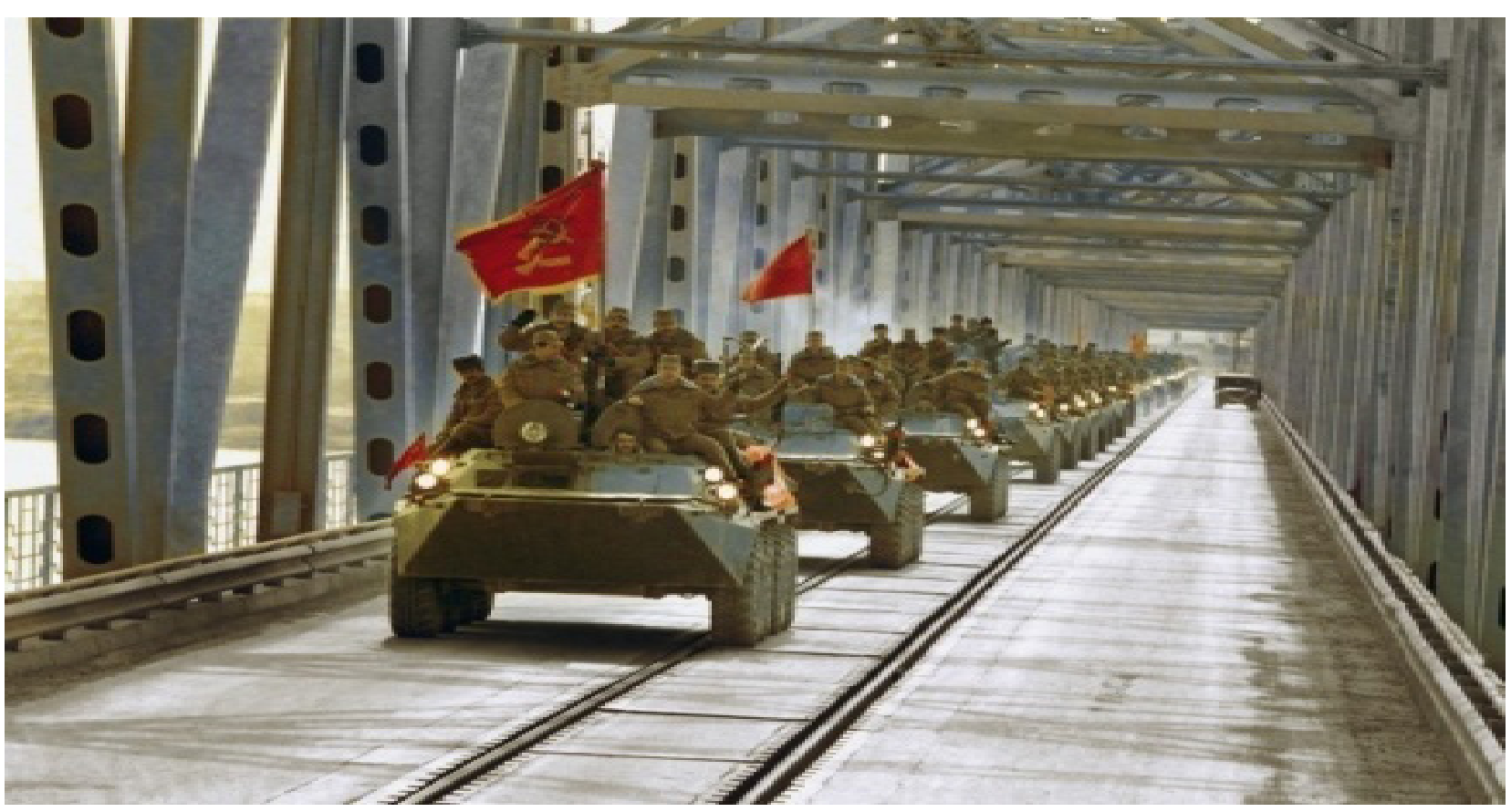

40-армия қолбасшысы Б. Громов бастаған колонна.

Термез, 15.02.1989 ж.

15 ақпан күні Ауғанстанмен шекаралас Термезге жақын биік қияларда кеңес жерінің оңтүстік шекарасына қарай көз салған әйелдер өз ұлдарын, күйеулерін, сүйіктілерін, жиналған жұрт өз азаматтарын ұзақ сағаттар бойы күтті. Ауған тарапынан кезекті колонна қашан келетінін ешкімде білмеді. Тіптен алыс жақтардан да адамдар келіп күтті. Тіптен қаралы қағаз алғандарда үмітпен келіп ол жаққа қарап отырды (Правда, 1989).

Мұнда Кеңес Одағының Батыры генерал-лейтенант 40-армияның соңғы қолбасшысы Б.В. Громов басшылығындағы барлаушылардың екі батальоны келіп тоқтады. Көптен күткен 15 ақпан да келді. Колонна кеңес және ауған жағалауларын біріктіруші көпірге көтеріліп Кеңес Одағы шекарасына жақындап келді. Алдыңғы қорғаныс машинасында жауынгерлік ту желбіреп көрінді. Кеңес жағалауына жете келе генерал-лейтенант Б.В. Громов қорғаныс машинасынан жерге түсіп, шекара қызыл сызығын жаяу кесіп өтті. Әрине, бұл Ауғанстанда бес жарым жыл соғысқан оның соңғы метрлерді жаяу жүріп өту құқы еді.

Шекарадан соңғы болып өткен кеңес әскерлерінің шектеулі контингентінің қолбасшысы генерал-лейтенент Б.В. Громов КСРО Қарулы күштері басшылығының өкілі, армия генералы Н.И.Поповқа кеңестік әскерлердің Ауғанстаннан әкетудің толық аяқталғанын баяндады.
Амудария жағалауында кеңес жауынгерлерін мыңдаған адамдар - Термездің тұрғындары, солдаттар мен офицерлердің туған-туысқандары кеңес және шетел журналистері қарсы алды. Салтанатты митингі болды.

Ауған соғысынан оралған жауынгерлерді Өзбекстан Республикасы облыстық партия комитетінің бірінші хатшысы С. Мамарасулов, Өзбекстан компартиясы Орталық комитетінің екінші хатшысы В.П. Анишев, Ұлы Отан соғысының ардагері А.Р. Исмайлов құттықтады. Ұлдарын сағына күткен аналар атынан сөйлеген В.Г. Сергачеваның сөзі ерекше тебірентті. Жауынгерлік туды желбіретіп Ауғанстан территориясынан шыққан бірінші қорғаныс машинасында оның ұлы лейтенант А. Сергачев қайтып оралған еді. Митингіде КСРО Қорғаныс министрінің бүгін Ауғанстаннан қайтып оралған барлық солдаттар мен офицерлерді бағалы сыйлықтармен марапаттау туралы бұйрығы оқылды.

Ауғанстан территориясынан ең соңғы болып шыққан кеңес әскерлерінің шектеулі контингенті қолбасшысы генерал-лейтенант Б.В. Громов митингіде: «Біз өз міндетімізді орындап, өз борышымызды өтедік. Бұл Кеңес Армиясының солдаттарының, сержанттарының, прапорщиктерінің, офицерлерінің және қызметкерлерінің мүлтіксіз атқарған еңбегінің 
нәтижесі. Бүгін Ауғанстан территориясында бірде-бір Кеңес әскерінің жауынгері қалған жоқ. Біздер үшін Отанына тірі қайтпағандар қайғысы ешқашанда өз орнын толтырмайды. Біздер соғыста жан тапсырған қарулас жауынгерлерімізді ешқашан ұмытпаймыз», деп сөз сөйледі (Правда, 1989).

Осы күні шекараны кесіп өту Кушка бағытында да өтті. Дауылы мен аязы азынап тұрған осы күні барлық адамдар шекара бекетіндегі таяқшаның көтерілуін асыға күтті. Жергілікті уақыт бойынша 8.20-да соңғы кеңес әскерлерінің әкетілуі басталды. Марш әуені астында жауынгерлік туды желбірете отырып, мотоатқыштар батальоны келді. Бас қорғаныс машинасында КСРО Қорғаныс министрінің белгісі болды. Жауынгер-интернационалистер колоннасы кең тікұшақтар алаңына жол алды. Мұнда салтанатты митинг өтті. Мұнда КСРО ОК, КСРО Жоғары Кеңес Президиумы, КСРО Министрлер Кеңесінің Ауғанстаннан оралған кеңес әскерлеріне арналған үндеуі оқылды. Мұнда негізінен мынадай сөздер айтылды: «Отан сіздерді мақтан тұтады! Отан сіздерге алғысын білдіреді! Отан сіздерге сенеді!» делінді (Правда, 1989).

\section{Қорытынды}

Жалпы, он жылға созылған бұл соғысқа КСРО-дан 620 мың адам қатысып, оның 14 мың 453 адамы ұрыс даласында мерт болды. Қазақстаннан 22 мың адам бұл соғыстың отына күйіп, 1000-ға жуық жерлесіміз соғыс салдарынан жат жерде жан тапсырды. Соғыста қаза болған ауғандықтардың саны белгісіз. Қолда бар мәліметтерде бірден 2 млн адамға дейін ауытқиды. 1979 жылы 25 желтоқсанда КСРО Қорғаныс министрінің арнайы бұйрығы бойынша көрші ел шекарасын кесіп өтіп, Ауғанстан территориясындағы соғыс қимылына қатысқан кеңес әскерлерін Ауғанстаннан әкету жұмысы 1989 жылы 15 ақпанда осылай аяқталды. Бұл күн кеңес әскерлерінің шектеулі контингенті қатарында сапқа тұрып, Ауған соғысына қатысқан жауынгерлер үшін және барша халық үшін соғыстың аяқталу күні ретінде тарихи датаға айналды. Кеңес әскерлерінің Ауғанстан территориясынан әкетілуі шын мәнінде тарихи оқиға болды. Соғыс ауған халқы мен кеңес әскерлеріне көп рухани жарақат әкелді. Кеңес әскерлерінің қатысуымен 110 айға созылған Ауған соғысы осылай аяқталды.

\section{Әдебиеттер}

Васильев Н.М. (2014). Уроки необъявленной войны. К 25-летию вывода советских войск из Афганистана // Военноисторический журнал. №2.

Возвращение домой (1989), Правда. 16 февраль.

Гареев М. (2002). Афганская страда. Москва.

Гареев М. (2002). Моя последняя война. Москва.

Завершение войны в Афганистане // biofile.ru Қаралған күні: 5.01.2019.

Заявление советского правительства (1989). Правда. 16 февраль.

Как мы уходили из Кабула // www.pogranec.ru. Қаралған күні: 5.01.2019.

Коргун В. Г. (2004) История Афганистана ХХ век. Москва: ИВ РАН: Крафт+.

Ляховский А.А. (1991). На афганской выжженной земле // Коммунист Вооруженных Сил. №22. 68-77 с.

Как мы уходили из Кабула // www.pogranec.ru Қаралған күні: 5.01.2019.

Обращение ЦК КПСС, Президиума Верховного Совета СССР, Совета Министров СССР, к советским воинам, вернувшимся из Афганистана (1989). Правда. 16 февраль.

Простаков С. (2013). За годы войны погибло от 1 до 1,5 млн жителей Афганистана // Русская планета. 30 декабря.

Сайлан Б.С. (2001). Ауған соғысының ақиқаты. Алматы: Қазақпарат.

Сайлан Б. (2018). Біз болған соғыс: монография. Алматы: Қазақ университеті.

Сайлан Б. (1996). Ауғанстан ақиқаты // Қазақ тарихы. №4. 47-51бет.

Сайлан Б. (2009). Ауған синдромы // Егемен Қазақстан. 25 ақпан.

Советские войска окончательно покинули Афганистан // eurasia.expert Қаралған күні: 5.01.2019.

\section{References}

Vasılıev N.M Uroki neobıavlenno1 voiny. K 25-letıy vyvoda sovetskıh voisk 1z Afganıstana [lessons of undeclared war. To the 25th anniversary of the withdrawal of Soviet troops from Afghanistan] // voenno-1storichesk11 jyrnal

Vozvrashenie domo1 (1989). [Homecoming] Pravda 1989-16 fevral

Gagreev M. (2002). Afganska1a strada [Afghan country] Moskva.

Gagreev M. (1996). Moıa posledniaia voına [May last war] Moskva. 
Za1avlenie sovetskogo pravitelstva (1989). [Soviet government statement] Pravda. 16 fevral

Zavershenie voiny v Afganistane [Ending war in Afghanistan] // biofile.ru Date: 5.01.2019.

Kak my uhodıl1 1 Kabyba [How we left from Kabul] // www.progranes.ru Date: 5.01.2019.

Korgyn V.G (2004) Istoria Afganistana XX vek [The history of Afghanistan in the 20thcentury] Moskva: IV RAN: Kraft.

Liahovsk11 A.A (1991). Na afgansko1 vyjenno1 zemle [On Afghan scorched earth] Kommynıst Voryjennyh S11. 22-68-77s

Obrashenıe SK KPSS, Presıdıym Verhovnogo Soveta SSSR, Soveta Minıstrov SSSR, k sovetskım voınam, vernyvshımsıa $1 \mathrm{z}$ Afganistana (1989) [Appeal CC. CPSU,Presidium of the Supreme Council USSR, Council of Ministers USSR, to the Soviet soldiers , returning from Afghanistan] Pravda 1989. 16 fevral.

Prostakov S. (2013). Za godyvoinypogibloot 1 do 1,5 mlnjitele1Afganistana [During the war years, from 1 to 1.5 million people in Afghanistan died] // Ryska1a planeta. 30 dekabria.

Sa1lan B.S (2001), Aygan sogysynyn akıkaty [Truth of Afghanistan]. Almaty: Kazakparat.

Sa1lan B. (2018). Biz bolgan sogys: monografia [The war we were on]. Almaty: Kazak Y niversiteti.

Sovetskı voıska okoncatelno pokınylı Afganıstan [Soviettroops finally left Afghanistan] // eurasia.expert Date: 5.01.2019. 